\title{
Pumice stones as potential in-situ burning enhancer
}

\section{Rojas Alva, U.; Andersen, Bjørn Skjønning; Jomaas, Grunde}

\section{Published in:}

Cold Regions Science and Technology

Link to article, DOI:

10.1016/j.coldregions.2017.12.004

Publication date:

2018

Document Version

Peer reviewed version

Link back to DTU Orbit

\section{Citation (APA):}

Rojas Alva, U., Andersen, B. S., \& Jomaas, G. (2018). Pumice stones as potential in-situ burning enhancer. Cold Regions Science and Technology, 146, 167-174. https://doi.org/10.1016/j.coldregions.2017.12.004

\section{General rights}

Copyright and moral rights for the publications made accessible in the public portal are retained by the authors and/or other copyright owners and it is a condition of accessing publications that users recognise and abide by the legal requirements associated with these rights.

- Users may download and print one copy of any publication from the public portal for the purpose of private study or research.

- You may not further distribute the material or use it for any profit-making activity or commercial gain

- You may freely distribute the URL identifying the publication in the public portal

If you believe that this document breaches copyright please contact us providing details, and we will remove access to the work immediately and investigate your claim 
PUMICE STONES AS POTENTIAL IN-SITU BURNING ENHANCER

U. Rojas Alva ${ }^{1,2}$, Bjørn Skjønning Andersen ${ }^{1}$, Grunde Jomaas ${ }^{1,2}$

${ }^{1}$ Civil Engineering Department, Technical University of Denmark, Denmark

${ }^{2}$ BRE Centre for Fire Safety Engineering, the University of Edinburgh, United Kingdom

Keywords: In-situ burning, Pumice stones, burning efficiency, burning enhancement, combustion products

\section{Abstract (less than 150 words)}

Small-scale and mid-scale experiments were conducted in order to evaluate pumice stones as a potential enhancement for in-situ burning (ISB). Four oil types, several emulsification degrees of one crude oil were studied. In general, it was observed that the pumice stones did not improve the burning efficiency (BE). In fact, for large pumice coverage ratios, the BE was affected negatively, especially for the emulsified crude oil, which is the most likely condition of the oil that may be subjected to ISB. Furthermore, it was observed that a relatively large amount of the pumice stones were sinking during and after the burn, thus bringing the oil into the water column. Finally, the species production of $\mathrm{CO}$ and $\mathrm{CO}_{2}$ was not reduced. Based on the presented results, pumice stones have a negative impact on the efficiency of ISB, and they are ruled out as an ISB enhancer and should not be used in relation to ISB. 


\section{INTRODUCTION}

After the first major oil spill happened in the 1950s, both government officials and researchers have put special emphasis on remediation of spilt oil on the sea, and even more so after the Deepwater Horizon oil spill [1]. During an offshore oil spill, there are several techniques to remove the oil from the water surface. One method that has been widely used is the in-situ burning (ISB) of oil on water. For example, ISB accounted for about 21 percent of the total clean-up by the three main methods (dispersants, mechanical and ISB) of the oil spill in the Gulf of Mexico (Federal Interagency Solutions Group, 2010) [2]. This technique consists of igniting the oil, at or near the spill site and letting the oil burn until most of the oil spilt has transformed into gases and soot. The method has been shown to have high elimination rates and high efficiency of burn. It has been reported in a review of several studies [1] that up to 90-99\% of removal efficiency can be achieved or lower depending on the weathering state of the oil which evaporates and emulsifies with the seawater [3]. The drawbacks associated with ISB are a generation of toxic gases, $\mathrm{CO}, \mathrm{CO}_{2}$ and soot, and the sinking of oil residues [1,3]. In order to diminish these problems, several techniques have been explored to enhance the burning, such as herding agents [4-6], adding combustion promoters [1], and the usage of pumice stones as a burning enhancer was proposed by some companies. It has been claimed that less smoke was observed when the oil on water was burnt with pumice stones than without. Moreover, since the pumice stones float on water due to their low density compared to water, no sinking of residues could eventually happen since the residues cling to the pumice stones.

An experimental study was undertaken to quantify the effects of introducing pumice to in-situ burning experiments. The results are presented in the following, where ignition and combustion-related parameters to ISB of crude oil on water are analysed. The majority of tested pumice stones had a diameter of approximately $35 \mathrm{~mm}$ to $50 \mathrm{~mm}$. Larger diameters were also tested but did not yield significant differences. The main parameters studied were the burning efficiency, the burning time, the mass flow rate and the yield of two combustion species ( $\mathrm{CO}$ and $\left.\mathrm{CO}_{2}\right)$. In addition, the oil residues' behaviour was studied.

\section{METHOD}

Various parameters, related to ignition and combustion of crude oils on water, were systematically studied in a series of small-scale and mid-scale experiments. The scenarios are presented in the following:

\section{A. Different crude oils:}

Four crude oils were investigated: Grane, Alaska North Slope (ANS), Danish Underground Consortium (DUC) and Siri. Grane is an asphaltenic crude oil with a high content of resins and is able to form stable emulsions [3]. ANS is a medium 
grade crude oil, with lower density and viscosity than Grane. DUC is a low sulphur, naphthenic type North Sea crude oil with a medium content of waxy components [7]. And the last, Siri, is a paraffinic crude oil with a high content of waxy components and medium evaporative losses compared to other crude oils. The measured densities and viscosities of the crude oils are displayed in Table 1.

\section{B. The degree of emulsification:}

Fresh Grane crude oil was emulsified with 5, 10 and $15 \%$ water content, respectively. The water-in-oil emulsions were produced by the rotating flask technique, a modified technique based on Mackay and Zagorski [8]. The measured physical properties of the emulsions are displayed in Table 1. The artificial emulsions created for this study can be considered unstable, following classification given by other studies [9]. In real scenarios, the spilt oil undergoes a weathering process where it evaporates and emulsifies. During emulsification, small water droplets penetrate into the oil slick layer due to mechanical movement caused by wave-action. Evaporation of the lightest components will onset the crystallisation and precipitation of the asphaltenes along with resins in the crude oil; it is well accepted that these agents can stabilise the water droplets in the oil layer [9,10,1]. In order to ignite the emulsified oil, it is first required to break the emulsion by increasing the temperature until the water droplets evaporate, which leaves the oil to evaporate and produce the required gas mixture to sustain combustion. Highly stable emulsified crude oils (higher content of water) will theoretically require higher energy, which is practically not feasible in the Arctic context. Therefore, unstable emulsions were used for this study, since it enabled the study to assess the effect of the pumice stones on the ISB.

Table 1 - Measured densities and viscosities of three oils and three water-in-oil emulsions.

\begin{tabular}{|c|c|c|c|c|c|c|c|}
\hline \multirow{2}{*}{ Properties (at $\left.25^{\circ} \mathrm{C}\right)^{1}$} & \multicolumn{4}{|c|}{ Oil type } & \multicolumn{3}{|c|}{ Emulsion type } \\
\hline & Grane & ANS & Siri & DUC & Grane_5\% & Grane_10\% & Grane_15\% \\
\hline Bulk density $\left[\mathrm{g} / \mathrm{cm}^{3}\right]$ & 0.918 & 0.871 & 0.883 & 0.870 & 0.935 & 0.933 & 0.938 \\
\hline Kinematic viscosity $\left[\mathrm{mm}^{2} / \mathrm{s}\right]$ & 143.2 & 12.3 & 6.4 & 9.16 & 157.0 & 183.7 & 199.1 \\
\hline Dynamic viscosity [mPa.s] & 131.4 & 10.7 & 7.6 & 6.5 & 169.3 & 196.8 & 212.7 \\
\hline
\end{tabular}

\footnotetext{
${ }^{1}$ The properties of the fresh crude oils and water-in-oil emulsions are average values measured at $25{ }^{\circ} \mathrm{C}$ obtained from several measurements performed in the "Paar Stabinger Viscometer SVM 3000" apparatus. The apparatus follows various standards for measuring the kinematic viscosity (ASTM D7042, EN 16896, and DIN 51659-2), the dynamic viscosity (ASTM D7042), and the density (EN ISO 12185, ASTM D4052, and IP 365).
} 


\section{Pumice coverage ratios:}

Several pumice coverage ratios were tested, these ranged from 25 to $80 \%$. The pumice coverage ratio (PCR) is defined as:

$$
\text { PCR }=\frac{A_{\text {pumice }}}{A_{S}}[\%]
$$

Where $A_{\text {pumice }}$ is the area occupied by the pumice stones, and $A_{s}$ is the pool area or oil slick area. The first was calculated based on pictures that were taken from above the oil pool. The pictures were individually analysed using image processing software.

\section{Small-scale experiments}

The Crude Oil Flammability Apparatus (COFA) was developed to study in-situ burning of crude oils spilt on the water in a controlled laboratory environment [11,12], see Figure 1 . In the tests, the crude oil was poured into the Pyrex glass cylinder (PGC), 26cm diameter, along with the pumice stones (mechanically confined). Then, the pumice stones were stirred with a spatula in order to let them absorb oil during for approximately 10 minutes. Finally, the oil was ignited with a butane torch. The oil residues were collected with oil sorbent pads, which were dried along with the pumice stones (24 hours in an oven at $60^{\circ} \mathrm{C}$ ) and weighed.

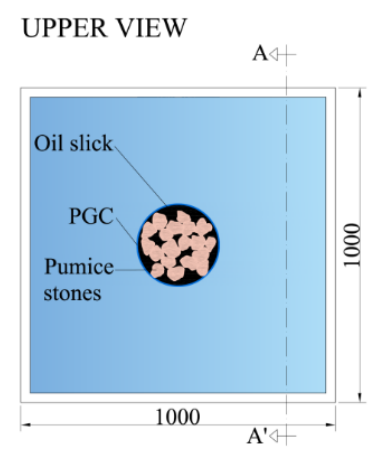

\section{SECTION A-A'}

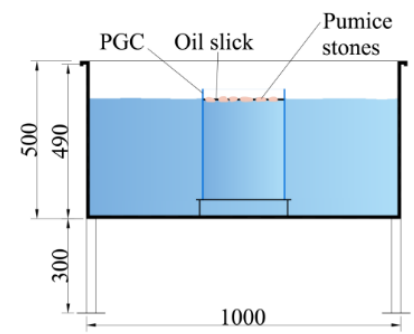

Figure 1 - Overview of the COFA with pumice stones. The dimensions are $\mathrm{mm}$. 


\section{Mid-scale experiments}

Two mid-scale experiment took place in a $20 \mathrm{~m}^{2}$ octagon water basin, see Figure 2. The first experiment was executed without the addition of pumice stones, and during the second experiment, pumice stones were added to obtain $20 \%$ PCR approximately. The weather conditions were very similar during both experiments. The water temperature, the air temperature and the air velocity around the water basin measured $5-6{ }^{\circ} \mathrm{C}, 2-6{ }^{\circ} \mathrm{C}$ and $1-2 \mathrm{~m} / \mathrm{s}$, respectively. The crude oil was poured onto the water and allowed to spread for 30 minutes. The oil was then chemically confined by applying from basin's edges $3 \mathrm{ml}$ of the herding agent OP40, which in turn was allowed to herd (towards the centre of the basin) the oil for 30 minutes. Then, the pumice stones were carefully distributed over the herded oil slick. Finally, the oil was ignited by applying a gelled batch of gasoline and diesel fuel. The oil slick thickness was estimated based on the area of the oil slick, the initial oil volume and the density of the oil. The area was estimated by processing manually the pictures taken by the video camera located above the water basin. The initial oil slick thickness (after herding) for both tests was $8 \mathrm{~mm}$, for the second test after adding the pumice stone the oil slick thickness increased to $10 \mathrm{~mm}$.
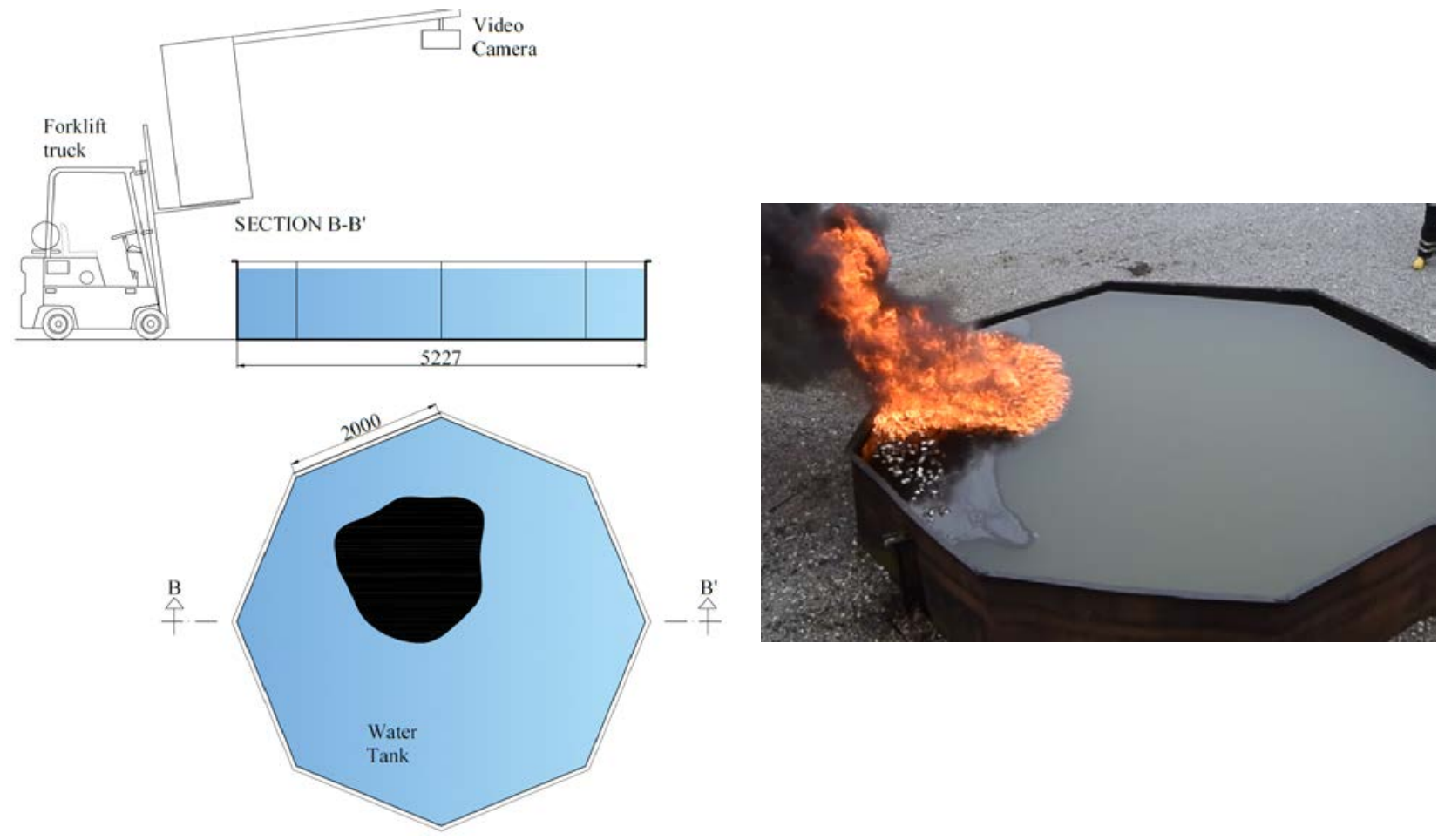

Figure 2 - The mid-scale experimental set-up with the upper schematic showing a side-view and the middle schematic showing a top view. The picture at the bottom is from one of the experiments (Grane crude oil and 25\% of PCR). The dimensions are in $\mathrm{mm}$. 


\section{Oxygen Consumption method}

The oxygen consumption method is based on the observation that, in general, the net heat of combustion is directly related to the amount of oxygen required for combustion [13]. The method was used to measure the oxygen consumption and gas flow rates during some of the small-scale in-situ burning experiments with oils and pumice stones. The method is mainly applied for determining the heat release rate. However, it is possible to measure other parameters, such as the specimen mass loss rate, the smoke obscuration generated, specimen ignitability, the effective heat of combustion and the yields of combustion products from the test specimen $\left(\mathrm{CO}\right.$ and $\left.\mathrm{CO}_{2}\right)$ [14].

\section{Parameters}

In the following explanation for each measured parameter is given:

\section{a) Burning efficiency}

The calculated burning efficiencies, $\mathrm{BE}_{\mathrm{oil}}$, are based on the initial oil amount and can be calculated by the following expression:

$$
B E_{\text {oil }}=100\left(1-\frac{m_{f}}{m_{0, o i l}}\right)
$$

Where $\mathrm{m}_{0, \text { oil }}$ is the mass of the initial amount of crude oil, $\mathrm{m}_{\mathrm{f}}$ is the mass of the oil residues left after burning. It is assumed that the water contained in the emulsion evaporates or mixes with the water in the tank during combustion. If after combustion, there was still some emulsion left, the water would evaporate in the drying out of the residues in the oven.

\section{b) Mass flow rate}

The mass flow rates of the species, $\mathrm{CO}$ and $\mathrm{CO}_{2}$, were measured by the oxygen consumption method presented by Janssens [15].

\section{c) Yield of species}

The yield of species is the mass of species $i$ produced per mass supply rate of the gaseous fuel [16], it is denoted as $y_{i}$ and define as:

$$
y_{i}=\frac{m_{i}}{m_{f}}
$$


Where $m_{i}$ is the mass of species $i$ produced, and $m_{f}$ is the mass of the gaseous fuel supplied, or the mass lost in gasification.

In order to estimate the yield of the two combustion species, $\mathrm{CO}$ and $\mathrm{CO}_{2}$, produced during the in-situ burning experiments, the total mass of each species produced was calculated. To do so, a trapezoidal numeric integration of the mass flow numerical data that was obtained by the oxygen consumption unit [17]. Then, the total mass of each species was divided by the mass lost during combustion by the crude oils.

\section{RESULTS AND DISCUSSION}

\section{Burning efficiency as a function of the pumice coverage ratio (PCR)}

The data from the small-scale experiments showing the burning efficiency as a function of pumice coverage for all crude oils and an emulsion is listed in Table 2. In most cases, it can be seen that the burning efficiency was not substantially improved at any pumice coverage factor. Solely, for Grane crude oil with pumice coverage of approximately 60\%, the burning efficiency was slightly improved. However, for pumice coverage higher than $60 \%$, the burning efficiency was negatively influenced, as can be seen in Figure 3.

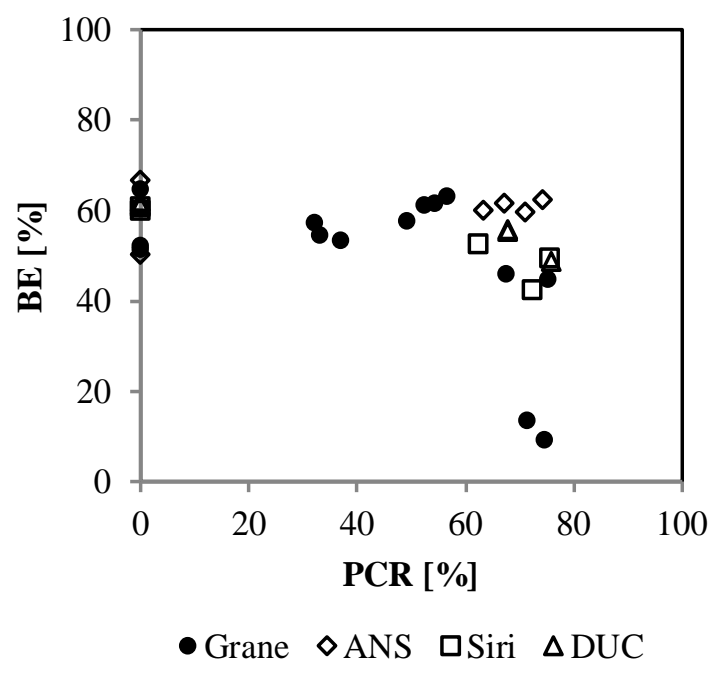

Figure 3 - Burning efficiency as a function of the PCR for Grane, ANS and Siri.

During the experiments with Grane, it was observed that the oil formed small pools between the pumice stones due to the buoyancy driven flows in the hot oil layer $[18,19]$. Due to this effect, the crude oil did not burn evenly and produced less energy than required to sustain pyrolysis at the oil surface. 
The data concerning ANS, DUC and Siri crude oils is also plotted in Figure 3. As in the Grane case, the burning efficiency was not improved for ANS. Nonetheless, no decay in the burning efficiency was observed for higher pumice coverage ratios, as opposed to what was observed for Grane. For pumice coverage ratios above $70 \%$, the burning efficiency of the DUC and Siri crude oils was negatively affected.

The effect of the pumice coverage ratio for Grane emulsions with 0, 5, 10 and 15\% water content can be seen in Figure 4.

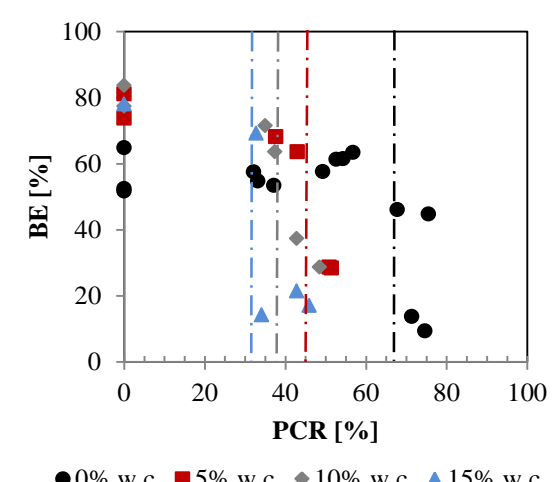

Figure 4-Burning efficiency as a function of the pumice coverage rate for 0, 5, 10 and 15\% Grane water-in-oil emulsion. The dashed lines represent the limit when the BE suffers a dramatic drop for each scenario.

It is clear that the burning efficiency is even more negatively affected for these scenarios. In all cases, a dramatic drop in burning efficiency was observed when the pumice coverage ratio was approximately higher than $30-45 \%$. Again, small pools were formed during the experiments as in the previous experiments with pure crude oils. In addition to the previous issue, more energy is required to evaporate the encapsulated water in the emulsion; thus the pumice stones will have a larger negative impact on the burning efficiency for emulsified oils. 
Table 2 - Average burning efficiencies results.

\begin{tabular}{|c|c|c|c|c|c|}
\hline Oil_water content & $\begin{array}{c}\text { Initial oil slick } \\
\text { thickness } \\
\text { [mm] }\end{array}$ & $\begin{array}{c}\text { PCR } \\
{[\%]}\end{array}$ & $\begin{array}{c}\text { Oil slick } \\
\text { thickness after } \\
\text { pumice [mm] }\end{array}$ & $\begin{array}{l}\text { Number of } \\
\text { experiments }\end{array}$ & $\begin{array}{c}\text { Average BE } \\
{[\%]}\end{array}$ \\
\hline \multirow{5}{*}{ Grane_0\% } & 5 & 0 & 5 & 4 & 55.5 \\
\hline & 5 & $\sim 40$ & 8 & 2 & 55.9 \\
\hline & 5 & $\sim 50$ & 11 & 2 & 62.1 \\
\hline & 5 & $\sim 60$ & 18 & 2 & 45.4 \\
\hline & 5 & $\sim 70$ & 19 & 2 & 11.6 \\
\hline \multirow{3}{*}{ Grane_5\% } & 5 & 0 & 5 & 2 & 77.5 \\
\hline & 5 & $\sim 40$ & 8 & 2 & 65.9 \\
\hline & 5 & $\sim 50$ & 10 & 2 & 28.5 \\
\hline \multirow{3}{*}{ Grane_10\% } & 5 & 0 & 5 & 2 & 80.5 \\
\hline & 5 & $\sim 40$ & 7 & 2 & 67.6 \\
\hline & 4 & $\sim 50$ & 8 & 2 & 33.0 \\
\hline \multirow{4}{*}{ Grane_15\% } & 4 & 0 & 4 & 1 & 78.1 \\
\hline & 4 & $\sim 30$ & 6 & 1 & 70.6 \\
\hline & 4 & $\sim 35$ & 6 & 2 & 41.7 \\
\hline & 4 & $\sim 40$ & 8 & 2 & 19.3 \\
\hline \multirow{3}{*}{ Siri_0\% } & 5 & 0 & 5 & 2 & 60.6 \\
\hline & 5 & $\sim 60$ & 13 & 2 & 52.6 \\
\hline & 5 & $\sim 75$ & 19 & 1 & 46.1 \\
\hline \multirow{3}{*}{ ANS_0\% } & 5 & 0 & 5 & 2 & 58.6 \\
\hline & 5 & $\sim \sim 60$ & 14 & 1 & 52.6 \\
\hline & 5 & $\sim 75$ & 19 & 2 & 46.1 \\
\hline \multirow{3}{*}{ DUC_0\% } & 5 & 0 & 5 & 2 & $\begin{array}{l}61.8 \\
\end{array}$ \\
\hline & 5 & $\sim 70$ & 15 & 2 & 56.0 \\
\hline & 5 & $\sim \sim 80$ & 21 & 1 & 48.9 \\
\hline
\end{tabular}

Two mid-scale experiments were performed, one without and one with pumice stones, respectively. The second experiment can be seen in Figure 2. The burning efficiencies obtained during both experiments were higher than those obtained during the small-scale experiments. Such a behaviour is most likely because more energy is generated during the combustion of larger amounts of fuels and thus more energy is radiated back, see Figure 5. It has been shown in pool fires that above a certain pool size diameter ( $>1 \mathrm{~m})$, radiation becomes dominant (as compared with convection) and it contributes largely to the burning mechanisms [20]. Therefore, a high BE is obtained with larger amounts of crude oils. The correlating behaviour indicates that the physical phenomena behind ISB could be scaled up. Hence, small-scale results could be extrapolated to real scenarios. As it was observed in the small-scale experiments, no improvement in burning efficiency was observed in the experiment with pumice stones, see Table 3.

Table 3 - Results from the mid-scale experiments.

\begin{tabular}{ccccccc}
\hline Experiment type & Oil type & $\begin{array}{c}\text { Amount } \\
\text { [l] }\end{array}$ & $\begin{array}{c}\text { Initial oil slick } \\
\text { thickness [mm] }\end{array}$ & $\begin{array}{c}\text { PCR } \\
\text { [\%] }\end{array}$ & $\begin{array}{c}\text { Oil slick thickness after } \\
\text { pumice [mm] }\end{array}$ & BE [\%] \\
\hline Without pumice stones & Grane & 20 & 8 & 0 & 8 & 77.7 \\
With pumice stones & Grane & 20 & 9 & 25 & 10 & 71.8 \\
\hline
\end{tabular}




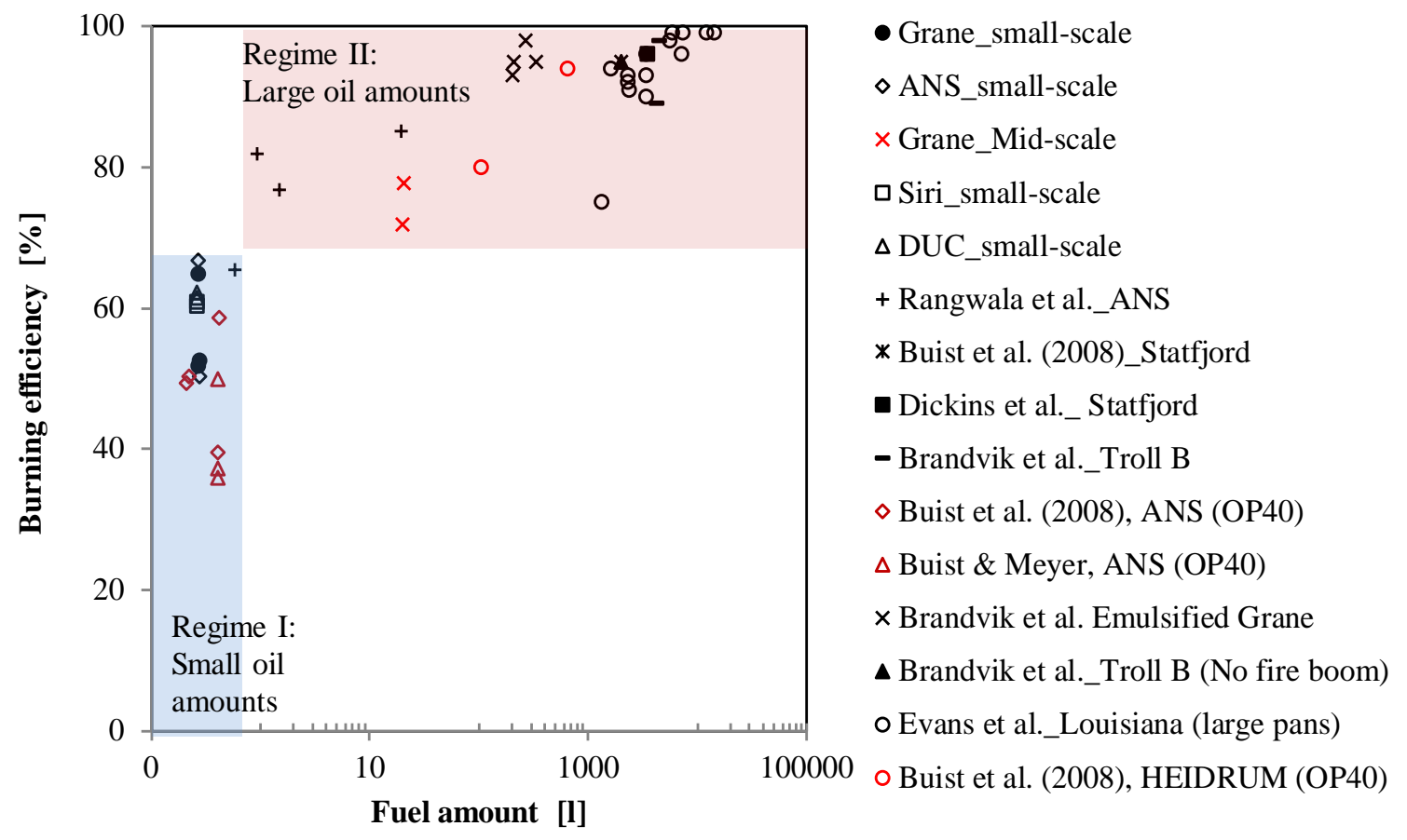

Figure 5 - Burning efficiency as a function of the fuel amount. Experimental data from several studies [1,5,21-27], where the oil was confined either mechanically or chemically (OP40 was a herding agent).

\section{Sinking of pumice stones during burning}

Another phenomenon observed during the small-scale and mid-scale experiments was that some of the pumice stones sank during the burning and immediately after the flames extinguished. This behaviour was in particular prevalent for large burning efficiencies for all of the four fresh crude oils, as it can be seen in Figure 6. On the contrary, quantitatively less sinking was observed during the water-in-oil emulsion experiments with pumice stones for most of the experiments, see Figure 7. 


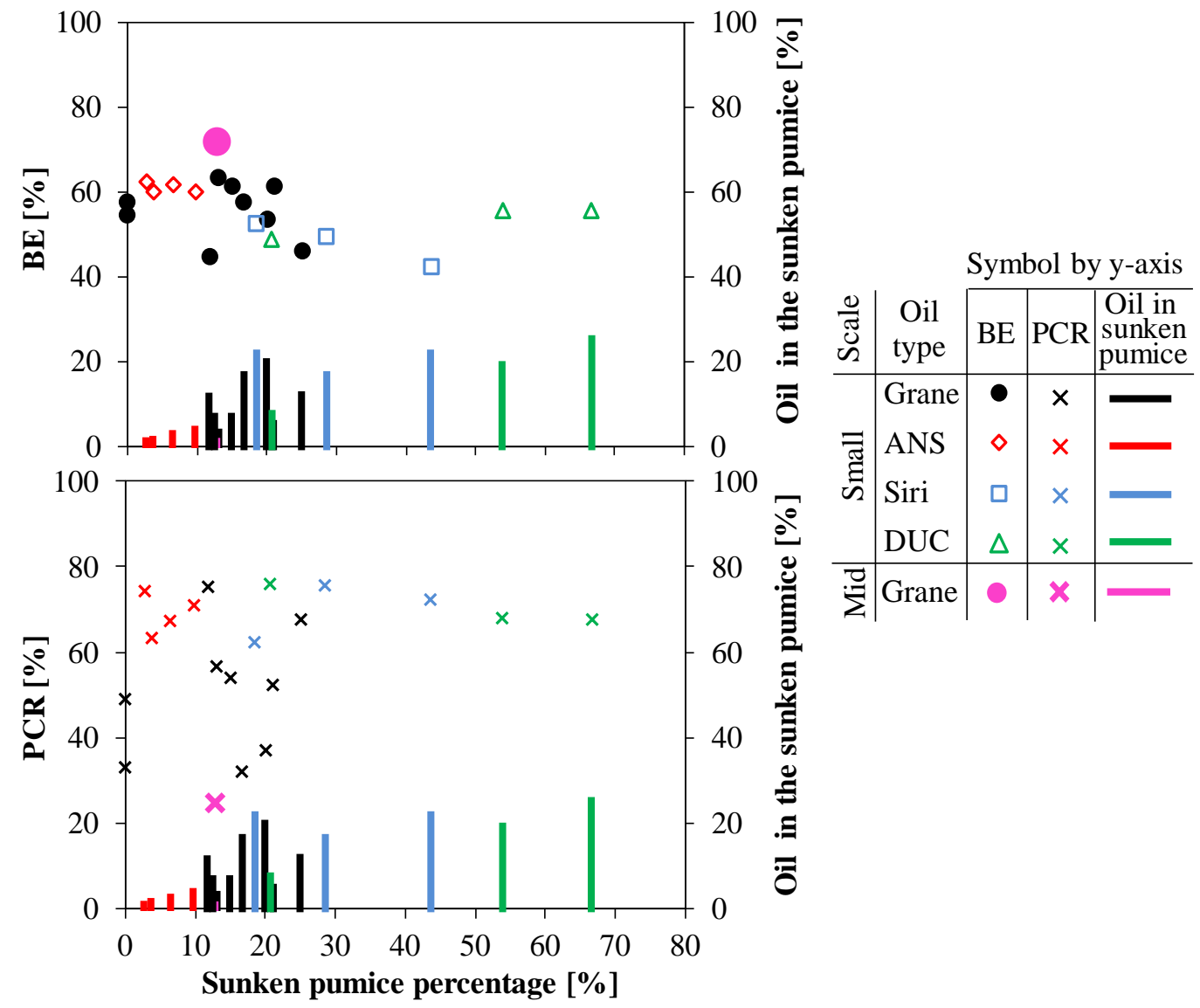

Figure 6 - Sunken pumice percentage as a function of the burning efficiency, the initial pumice coverage ratio (PCR) and the proportion of oil trapped in the sunken pumice. The results correspond to Grane, ANS, Siri and DUC crude oils of small-scale experiments and Grane of the mid-scale experiment.

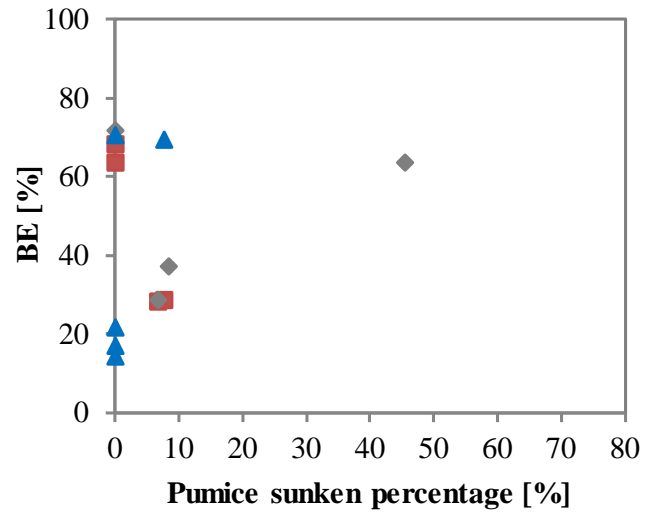

- Grane_5\% $\bullet$ Grane_10\% $\Delta$ Grane_15\%

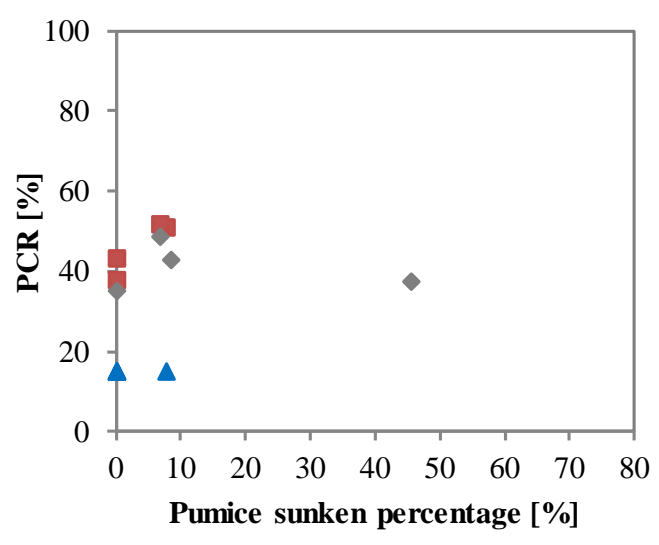

Grane 15\% $\bullet$ Grane 10\% $\Delta$ Grane 15\%

Figure 7 - Burning efficiency (left pane) and PCR (right pane) as a function of the sunken pumice percentage for various degree of emulsified Grane.

During combustion of the oil, the pumice stones floating along with the oil are subjected to high temperature from the oil surface $\left(\sim 300^{\circ} \mathrm{C}\right)$ and the flames (up to $700{ }^{\circ} \mathrm{C}$ ). Based on experimental results, Whitham and Sparks [28] claimed that 
for temperatures above $700^{\circ} \mathrm{C}$, any pumice stone with the lowest density (highest porosity) would sink. They also claimed that the higher the pumice temperature, the greater the proportion of steam generated and consequently more air is flushed out and water penetrates into most of the vesicles immediately.

The pumice stones absorb water and crude oil at the same time. During the combustion process, the lighter components vaporise first and then the heavier, hence the density of the oil residues increases [29]. In addition to the absorbed water, the oil residue also penetrates the pores in the pumice stone. As a consequence, the density of some of the pumice stone becomes heavier than the density of the water and sank. This will to some extent artificially increase the burning efficiency.

The sunken pumice percentage versus the burning efficiency results, though only for the crude oils (no emulsions), are plotted in Figure 6. As it can be seen, for ANS crude oil, up to $10 \%$ of the pumice stones had sunken after the flames extinguished. For Siri and DUC crude oils, the sunken pumice percentage worsens, with up to $44 \%$ and $67 \%$ of the pumice sinking, respectively. For the Grane crude oil, the sunken pumice percentage reached about 25\%. However, it should be highlighted that the burning efficiencies results are directly affected as part of the crude oil is trapped in the sunken pumice. As such, the relatively high burning efficiencies for the high sunken percentages are somewhat misleading A rough estimate of the oil that sank along the pumice is also given in Figure 6 (see bars), where is clear that for smallscale tests a relatively large proportion of the oil sank. Hence, the burning efficiency is artificially increased. Nonetheless, in the mid-scale test, this proportion was found to be 1\% approximately. It might be explained by the low PCR employed in the mid-scale test (around 26\%). It is not clear how the sinking of pumice stones is differently affected by the different oil types. There is a big difference between experiments with similar burning efficiencies; the pumice sunken percentage can vary quite substantially. This might be explained by the non-uniform pores composition of each pumice stone.

Nonetheless, it is clear that the heavy and medium oils, Grane and ANS, present a relatively lower pumice sunken percentage (lower than 20\%). Whereas, the waxy oils (DUC and Siri) are most likely to have a higher pumice sunken percentage (from 20 to $70 \%$ ).

\section{Burning time}

The burning time was determined from the moment the oil slick was ignited with the butane torch until the flames died out over the oil slick. Data from Grane and emulsified Grane experiments is plotted in Figure 8. The burning time remains 
quite similar for pumice coverage ratios up to $40 \%$. After that, the burning times seems to correlate proportionally to the pumice coverage ratios.

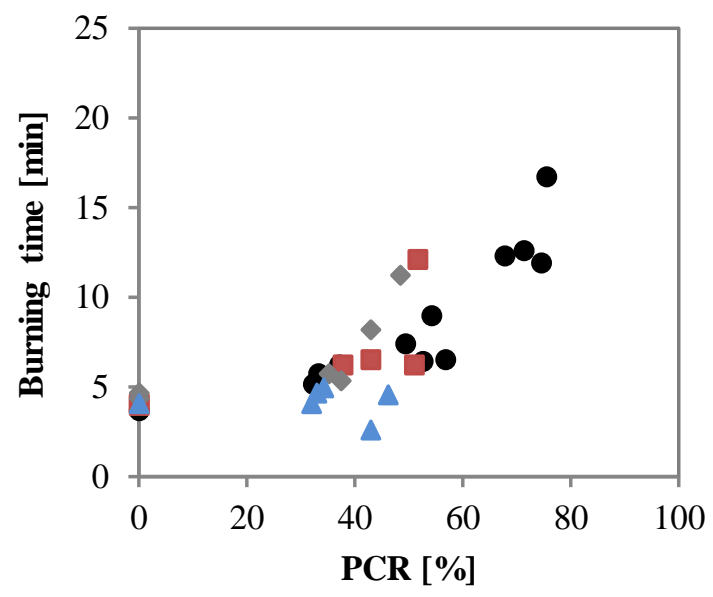

- $0 \%$ w.c. $5 \%$ w.c. $10 \%$ w.c. $\triangle 15 \%$ w.c.

Figure 8-Burning time as a function of the pumice coverage ratio (PCR). Data from small-scale experiments with Grane crude oil and several Grane water-in-oil emulsions.

Results concerning ANS, DUC and Siri crude oils are plotted in Figure 9. As in the previous case, the burning time increases with higher pumice coverage rates.

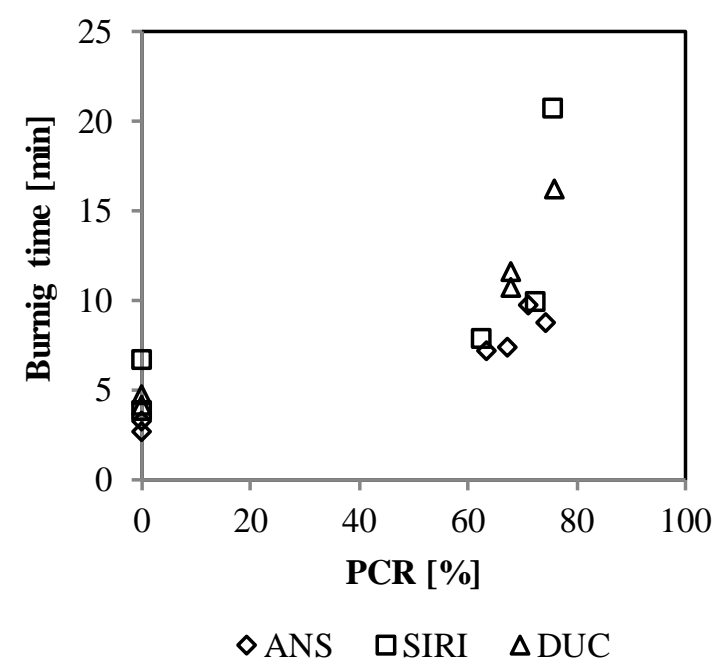

Figure 9 - Burning time as a function of the pumice coverage ratio (PCR). Data from small-scale ANS, Siri and DUC crude oils. 


\section{Smoke Production}

The measured mass flow rates of the two combustion species, $\mathrm{CO}$ and $\mathrm{CO}_{2}$, for two oils with two pumice coverage ratios, without pumice (0\%), are plotted in Figure 10 to Figure 13.
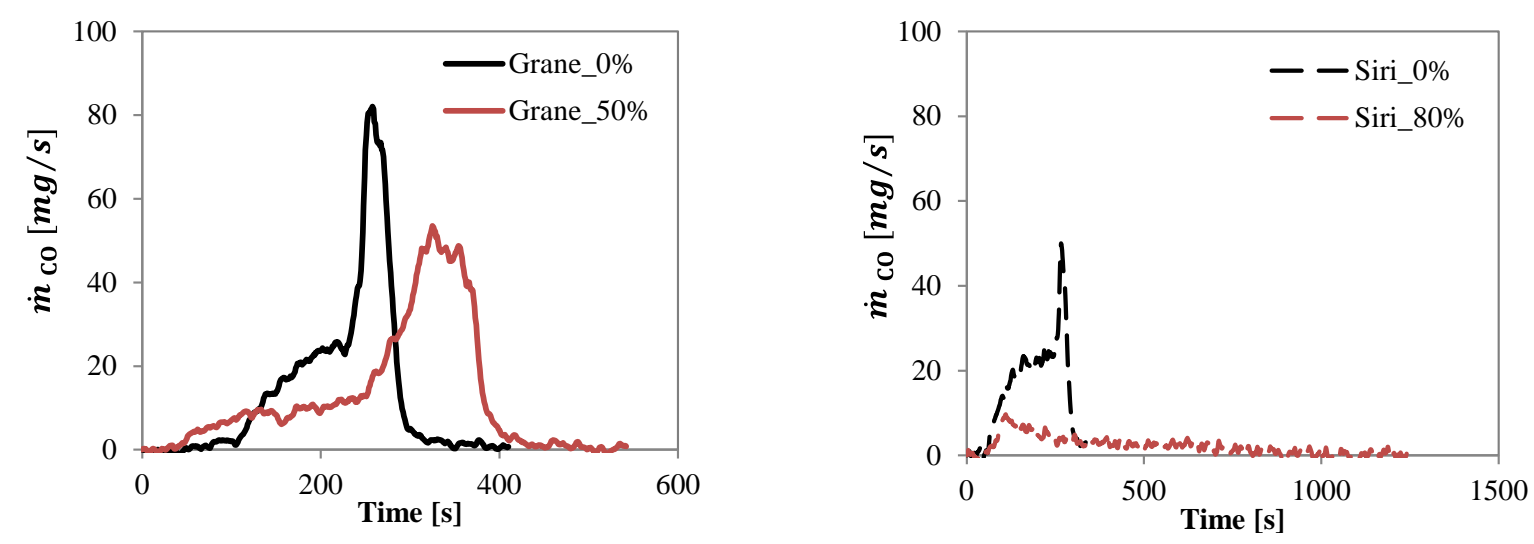

Figure 10 - Mass flow rate of carbon monoxide as a Figure 11 - Mass flow rate of carbon monoxide as a function of time for Grane crude oil for 0 and 50\% PCR function of time for Siri crude oil for 0 and $80 \%$ PCR (small-scale). (small-scale).
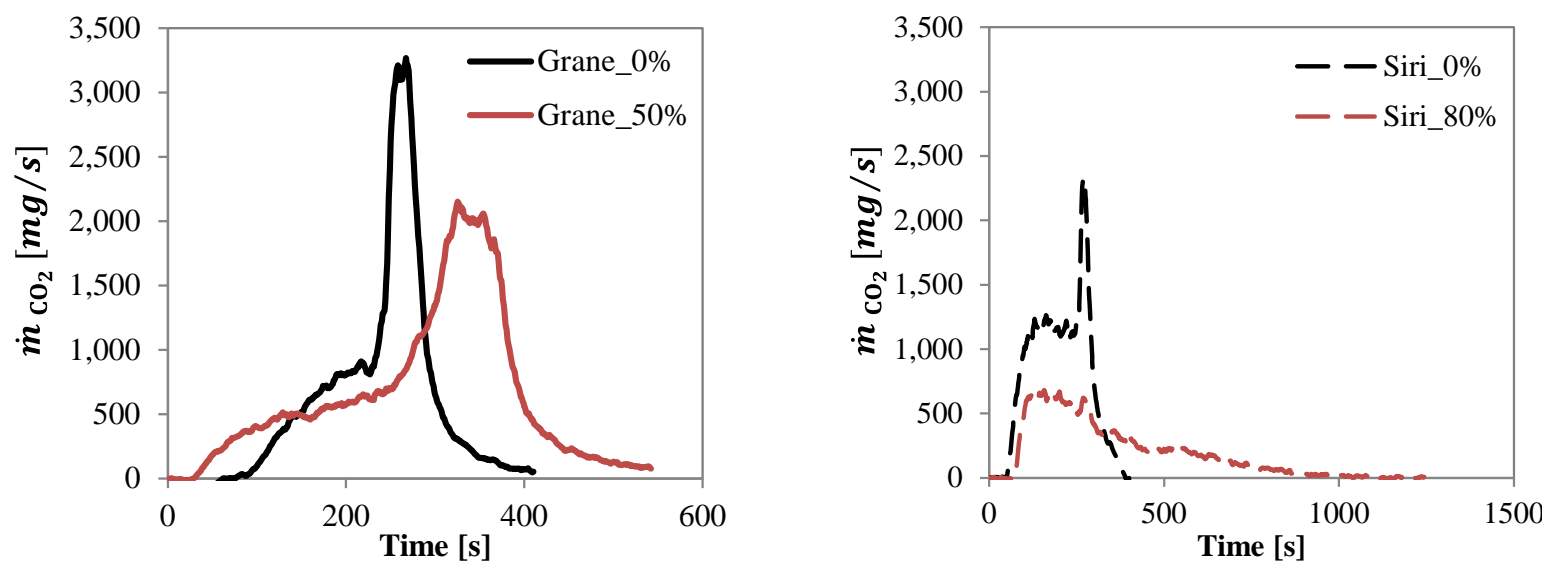

Figure 12 - Mass flow rate of carbon dioxide as a function

Figure 13 - Mass flow rate of carbon dioxide as a function of time for Grane crude oil for 0 and 50\% PCR (small- of time for Siri crude oil for 0 and 80\% PCR (small-scale). scale)

It is clear that adding the pumice stone as an enhancement to the combustion of the oil, increases the burning time significantly. For Grane experiment with 0 and 50\% pumice coverage ratio, peaks of measured mass flow rates are observed with off-set times, see Figure 10 and Figure 12. The peaks can be explained by the so-called "boilover phenomenon” that was observed during both experiments. The boilover is the disruptive burning of the fuel caused by the underlying layer of water superheating, resulting in boiling and splashing. It occurs when the temperature at the 
fuel/water interface reaches a constant temperature that is above the saturation temperature of the water [30]. This phenomenon has not been observed at actual ISB, most likely due to the sea currents constantly removing the heated water under the oil. In the case of the Siri crude oil, a measured peak mass flow is solely observed with no pumice coverage, see Figure 11 and Figure 13. On the contrary, no peak occurs for Siri with 80\% pumice coverage ratio. In this case, the pumice stones might have helped to prevent boilover. Presumably, less heat is exchanged downwards to the water layer.

The estimated yield of both combustion species for Grane, DUC and Siri crude oils is listed in Table 4. Even though the burning efficiencies differs for both test without and with pumice stones, and this consequently might influence the results. It can be seen that the yield of CO from Grane without and with pumice stones is very similar, the same occurs for Siri and DUC. The yield of $\mathrm{CO}_{2}$ for Grane experiments differs slightly. On the contrary, similar $\mathrm{CO}_{2}$ yields were found for DUC and Siri crude oils, although the obtained burning efficiencies by both oils with pumice stones are lower than their counterpart without pumice stone. The $\mathrm{CO} / \mathrm{CO}_{2}$ ratio for each testes were also estimated and are listed in Table 4. The $\mathrm{CO} / \mathrm{CO}_{2}$ ratio is an index of the incompleteness of combustion. For Grane the $\mathrm{CO} / \mathrm{CO}_{2}$ ratio slightly increases with the addition of pumice stones, which means poorer combustion. However, for Siri and DUC the CO/CO 2 ratio suffers a slight decrease when adding pumice stones, which would imply slightly better combustion. This contradictory behaviour might obey to the nature of the crude oils. The crude oils are a formed by many light and heavy components; it remains unclear how these components form $\mathrm{CO}$ and $\mathrm{CO}_{2}$ during the burning process. As demonstrated by Laurens and co-workers, the vaporisation order rate at which the various crude oil' components vaporise is not steady [29]. Therefore, the yield of CO and $\mathrm{CO}_{2}$ species is non-steady. Only obtaining either full combustion or very similar BE for experiments would precisely give a qualitatively account to assess the impact of the pumice stones. Such a case is unpractical. It is obvious that the yields of the two combustion species are not proportional to the burning efficiency. Nonetheless, it is clear that adding pumice stones does not contribute to a reduction in the formation of $\mathrm{CO}$ and $\mathrm{CO}_{2}$ or to a better combustion $(\mathrm{CO} / \mathrm{CO} 2$ index). On the contrary, it might contribute to the formation of both species, especially, for Grane crude oil. 
Table 4 - Yield of two species for three oils types and two pumice coverages.

\begin{tabular}{|c|c|c|c|c|c|}
\hline $\begin{array}{l}\text { Oil } \\
\text { type }\end{array}$ & PCR [\%] & $\begin{array}{l}B E \\
{[\%]}\end{array}$ & $y_{C o}[g / g]$ & $y_{\mathrm{Co}_{2}}[\mathrm{~g} / \mathrm{g}]$ & $\begin{array}{c}\mathrm{CO} / \mathrm{CO}_{2} \\
{[-]}\end{array}$ \\
\hline \multirow{2}{*}{ Grane } & 0 & 52 & 0.03 & 1.86 & 0.018 \\
\hline & 50 & 62 & 0.05 & 2.50 & 0.020 \\
\hline \multirow{2}{*}{ Siri } & 0 & 61 & 0.05 & 2.70 & 0.017 \\
\hline & 80 & 50 & 0.03 & 2.53 & 0.011 \\
\hline \multirow{2}{*}{ DUC } & 0 & 62 & 0.04 & 2.14 & 0.017 \\
\hline & 70 & 56 & 0.02 & 2.07 & 0.012 \\
\hline
\end{tabular}

Based on visual observation it was claimed that less smoke was observed during experiments with pumice stones. It indeed seems that less smoke is produced when adding pumice stones. However, this observation is due to longer burning times; thus spreading the smoke production over a larger time span. Most likely less soot is formed when pumice is added. Combining these two factors could explain that "less smoke" was observed.

\section{CONCLUSIONS}

Even though the experiments with pumice burned longer than the equivalent experiments without pumice, the experimental small-scale and mid-scale data showed that the addition of pumice stones does not improve the burning efficiency significantly. Equal or marginally better burning efficiencies were achieved when there were pumice stones at lower coverage ratios. A negative effect was observed when the pumice coverage rate was larger than $50-60 \%$ and 30 $45 \%$ for crude oils and emulsified oils, respectively. The burning time was increased proportionally for pumice coverage ratios above $40-50 \%$. In the case of Grane, the burning time increased three times for the largest pumice coverage ratio. The sinking of pumice stones contaminated with oil were observed during experiments, and especially in an experiment with high burning efficiencies and for waxy oils (DUC and Siri). It was possible to roughly estimate the amount of absorbed oil by the pumice stones that sank; this oil residue was accounted for in the burning efficiency calculations. The sinking of the pumice stone with oil residues could potentially pose a separate environmental hazard, and at the same time give a wrong estimate of the success of the burn. It was noticed that part of crude oil sank along with the pumice, but the amount of oil leaving the surface this way could not be quantified in a consistent manner. Finally, based on the 
measurements, the total formation of the two combustion species, $\mathrm{CO}$ and $\mathrm{CO}_{2}$, was not significantly reduced by using pumice stones during combustion of the crude oils. The estimated $\mathrm{CO} / \mathrm{CO}_{2}$ ratio for each oil reflected the same.

The overall conclusion based on the experimental results is that the usage of pumice stones in association with the in-situ burning of oil on water was demonstrated to only have drawbacks and no benefits. Therefore, further speculations about pumice stones as an in-situ burning enhancer can be dismissed.

\section{Acknowledgments}

The authors would like to thank NOFO for the grant, DESMI for providing the Pumice stones and for the good discussions. And the authors are especially thankful to Nordsjælland Brandskole for support related to the mid-scale experiments. 


\section{References}

[1] I.A. Buist, S.G. Potter, B.K. Trudel, S.R. Shelnutt, A.H. Walker, D.K. Scholz, P.J. Brandvik, J. FrittRasmussen, A.A. Allen, P. Smith, In Situ Burning in Ice-affected waters: State of Knowledge report, 2013.

[2] The Federal Interagency Solutions Group, Oil Budget Calculator Deepwater Horizon, (2010).

[3] J. Fritt-Rasmussen, In situ burning of Arctic marine oil spills - Ignitability of various oil types weathered at different ice conditions. A combined laboratory and field study, Technical University of Denmark, 2010.

[4] I. Buist, Mid-scale test tank research on using oil herding surfactants to thicken oil slicks in pack ice: An update, Environ. Canada Arct. Mar. Oil Spill Progr. Tech. Semin. Proc. 2 (2006) 691-709.

[5] I. Buist, S. Potter, T. Nedwed, J. Mullin, Herding Agents Thicken Oil Spills in Drift Ice to Facilitate In Situ Burning: A new Trick for an Old Dog, in: Int. Oil Spill Conf., 2008. doi:http://dx.doi.org/10.7901/2169-33582008-1-673.

[6] S.L. Ross Environmental Research Ltd., Research on Using Oil Herding Agents for Rapid Response In Situ Burning of Oil Slicks on Open Water - Final Report, Ottawa, 2012.

[7] DUC crude oil - Technical Description, n.d. http://www.maerskoil.com/operations/sales/oil-salesdenmark/pages/oil-sales-denmark.aspx.

[8] D. Mackay, W. Zagorski, Studies of water-in-oil emulsions., Ottawa, Ontario, 1982.

[9] M. Fingas, B. Fieldhouse, Studies of the formation process of water-in-oil emulsions, Int. J. Mar. Environ. Sci. Eng. Adm. Polit. Lawyers. 47 (2003) 369-396. doi:10.1016/S0025-326X(03)00212-1.

[10] M. Bobra, Water-in-oil Emulsification. A physicochemical study, in: Int. Oil Spill Conf., 1991.

[11] N.L. Brogaard, M.X. Sørensen, J. Fritt-Rasmussen, S.R. Ali, G. Jomaas, A new Experimental Rig for Oil Burning on Water - Results for Crude and Pure Oils, in: Proc. 11th Int. Symp. Fire Saf. Sci. Int. Assoc. Fire Saf. Sci., 2014. doi:1709a180-e352-42aa-99ca-c74197ce1ad6.

[12] L. Van Gelderen, N.L. Brogaard, M.X. Sørensen, J. Fritt-Rasmussen, A.S. Rangwala, G. Jomaas, Importance of the slick thickness for effective in-situ burning of crude oil, Fire Saf. J. 78 (2015) 1-9. doi:10.1016/j.firesaf.2015.07.005.

[13] C. Huggett, Estimation of Rate of Heat Release by Means of Oxygen-Consumption Measurements., Fire Mater. 4 (1980) 61-65.

[14] B. Dlugogorski, J. Mawhinney, V. Huu Duc, The Measurement Of Heat Release Rates By Oxygen Consumption Calorimetry In Fires Under Suppression, Fire Saf. Sci. 4 (1994) 877-888. 
doi:10.3801/IAFSS.FSS.4-877.

[15] M.L. Janssens, Measuring rate of heat release by oxygen consumption, Fire Technol. 27 (1991) $234-249$. doi:10.1007/BF01038449.

[16] B. Karlsson, J.G. Quintiere, Enclosure fire dynamics, CRC Press, 2000.

[17] I. MathWorks, Trapezoidal Numerical Integration, (n.d.). http://uk.mathworks.com/help/matlab/ref/trapz.html (accessed January 10, 2017).

[18] F.J. Higuera, Steady thermocapillary-buoyant flow in an unbounded liquid layer heated nonuniformly from above, Phys. Fluids. 12 (2000) 2186-2197. doi:10.1063/1.1287611.

[19] H. Farmahini Farahani, G. Jomaas, A.S. Rangwala, Effects of convective motion in n-octane pool fires in an ice cavity, Combust. Flame. 162 (2015) 4643-4648. doi:10.1016/j.combustflame.2015.09.021.

[20] D.T. Gottuk, D.A. White, Liquid Fuel Fires, in: SFPE Handb. Fire Prot. Eng., Springer New York, New York, NY, 2016: pp. 2552-2590. doi:10.1007/978-1-4939-2565-0_65.

[21] D. Dickins, P.J. Brandvik, J. Bradford, L. Faksness, L. Liberty, R. Daniloff, Svalbard 2006 Experimental Oil Spill Under Ice: Remote Sensing, Oil Weathering Under Arctic Conditions and Assessment of Oil Removal By in-Situ Burning, Int. Oil Spill Conf. Proc. 2008 (2008) 681-688. doi:10.7901/2169-3358-2008-1-681.

[22] P.J. Brandvik, S. Potter, S.E. Sørstrøm, Report no. 27: Tests of Fire-Resistant Booms in Low Concentrations of Drif Ice - Field experiments May 2009, 2010.

http://www.sintef.no/globalassets/project/jip_oil_in_ice/dokumenter/publications/jip-rep-no-27-fex2009fireboomfieldtests-final.pdf.

[23] I. Buist, P. Meyer, Research on Using Oil Herding Agents for Rapid Response In Situ Burning of Oil Slicks on Open Water, in: Proc. 35th AMOP Tech. Semin. Environ. Contam. Response, 2012.

[24] I. Buist, S. Potter, T. Nedwed, J. Mullin, Herding surfactants to contract and thicken oil spills in pack ice for in situ burning, Cold Reg. Sci. Technol. 67 (2011) 3-23. doi:10.1016/j.coldregions.2011.02.004.

[25] X. Shi, P.W. Bellino, A. Simeoni, A.S. Rangwala, Experimental study of burning behavior of large-scale crude oil fires in ice cavities, Fire Saf. J. 79 (2016) 91-99. doi:10.1016/j.firesaf.2015.11.007.

[26] D.. Evans, W.D. Walton, H.R. Baum, K.A. Notarianni, J.R. Lawson, H.C. Tang, K.R. Keydel, R.G. Rehm, D. Madrzykowski, R.H. Zile, In-situ Burning of Oil Spills: Mesoscale Experiments, in: Fiftheenth Arct. Mar. Oilspill Progr. Tech. Semin., Environment Canada, Edmonton, Canada, 1992: pp. 593-657. http://www.fire.nist.gov/bfrlpubs/fire03/PDF/f03159.pdf. 
[27] P.J. Brandvik, D.P. S, L.-G. Fakness, J. Fritt-Rasmussen, D.L. Ragnhild, F. Leirvik, Report no. 26:

Experimental oil release in broken ice. A large-scale field verification of resutls from laboratory studies of oil weathering and ingitability of weathered oil spills., 2010.

[28] A.G. Whitham, R.S.J. Sparks, Pumice, Bull. Volcanol. 48 (1986) 209-223. doi:10.1007/BF01087675.

[29] L. van Gelderen, L.M.V. Malmquist, G. Jomaas, Vaporization order and burning efficiency of crude oils during in-situ burning on water, Fuel. 191 (2017) 528-537. doi:10.1016/j.fuel.2016.11.109.

[30] J.P. Garo, P. Gillard, J.P. Vantelon, a. C. Fernandez-Pello, Combustion of Liquid Fuels Spilled on Water. Prediction of Time to Start of Boilover, Combust. Sci. Technol. 147 (1999) 39-59. doi:10.1080/00102209908924211. 